\title{
Infectious Cervicitis
}

National Cancer Institute

\section{Source}

National Cancer Institute. Infectious Cervicitis. NCI Thesaurus. Code C78360.

An infectious process affecting the uterine cervix. Causative agents include Neisseria gonorrhoeae, Chlamydia trachomatis, human papillomavirus, and herpes simplex virus.

Physical examination reveals an erythematous, raised lesion in the cervix and mucopurulent discharge. 